\title{
Literacy Acquisition. \\ The Role of Phonology, Morphology and Orthography, red. R. M. Joshi, Ch. K. Leong, B. L. J. Kaczmarek, Amsterdam - Berlin - Oxford - Tokyo - Washington 2003, s. 217
}

W listopadzie 2001 w Il Ciocco we Włoszech odbyło się dwutygodniowe szkolenie NATO Advanced Study Institute poświęcone badaniom nad czytaniem i pisaniem w różnych systemach językowych. Organizatorzy za cel postawili sobie przedstawienie i przedyskutowanie najnowszej wiedzy na temat wpływu fonologii, morfologii i ortografii na początkową naukę czytania i pisania. Pod koniec 2003 roku wybrane wystąpienia prezentowane w Il Ciocco ukazały się w wydaniu książkowym.

Praca Literacy Acquisition. The Role of Phonology, Morphology and Orthography warta jest przybliżenia polskiemu czytelnikowi z kilku powodów. Przede wszystkim badania nad czytaniem i pisaniem w różnych systemach językowych prowadzone są intensywnie od wielu lat ${ }^{1}$, natomiast wyniki tych badań raczej nie są szeroko znane w Polsce. Być może właśnie z powodu utrudnionego dostępu do literatury obcojęzycznej. Ponadto, do tej pory polskie uczestnictwo w międzynarodowych badaniach nad czytaniem i pisaniem było raczej słabo reprezentowane. Książka Literacy Acquisition może być uznana za zwiastun pozytywnych zmian w tym względzie: zawiera dwa artykuły autorstwa polskich naukowców.

1 O popularności tego obszaru badawczego świadczą m.in. liczne prace wydane $w$ ostatnim dziesięcioleciu, por. np. Feldman L. B. (red.), Morphological aspects of language processing, Hillsdale 1995; Taylor I., Olsen D. R. (red.), Scripts and literacy, Dordrecht 1995; Perfetti C. A., Rieben L. (red.), Learning to spell: research, theory, and practice across languages, Mahwah, London 1997; Leong C. K., Joshi R. M. (red.), Cross-language studies of learning to read and spell, Dordrecht 1997; Joshi M. (red.), Linguistic relativity of orthographic and phonological structures, Dordrecht 2003. 
Prezentowana książka składa się z czterech części, omawiających kolejno wpływ wrażliwości fonologicznej na naukę czytania i pisania, wpływ ortografii na naukę czytania, problematykę nabywania umiejętności pisania oraz integracji czynników ortograficznych i fonologicznych $\mathrm{w}$ nauce czytania.

Część I Phonological Sensitivity in Reading and Writing (s. 3-66) zawiera cztery artykuły. J. E. Gombert (Francja) w tekście Learning to Read: Which Codes Are Concerned? At Which Level of Cognitive Control?, powołując się na badania francuskojęzycznych dzieci, dowodzi, że w początkowej nauce czytania ważne są nie tylko podstawowe umiejętności fonologiczne $\mathrm{w}$ procesie dekodowania, czyli wiedza o zależnościach między fonemem a grafemem (graphem-phonem correspondences), ale również wiedza metalingwistyczna, którą dzieci zdobywają podczas nauki czytania i pisania. Wiedza ta dotyczy przede wszystkim odpowiedniości między ortografią a morfologią (orthography-morphology correspondences). Gombert podkreśla, że dotychczasowe modele uczenia się czytania ignorowały dwa bardzo istotne fakty: wiedzę epijęzykową (nabywaną automatycznie, niekoniecznie świadomie) posiadaną przez dziecko przed rozpoczęciem nauki czytania oraz modyfikację tej wiedzy dokonującą się $\mathrm{w}$ trakcie nauki czytania.

O roli przyswajanej podświadomie, bez werbalnych instrukcji nauczyciela, wiedzy metajęzykowej w nauce czytania i pisania pisze również Bożydar L. J. Kaczmarek (Polska) w artykule Phonological Awareness and Ability to Read and Write. Autor, przywołując wyniki badań pisma polskich agrafików, czyli ludzi, którzy stracili umiejętność pisania, poświadcza rolę świadomości językowej w procesie czytania, ale jednocześnie krytykuje uproszczenia, które wpłynęły na dotychczasowe rozumienie tego procesu. Zalicza do nich m.in. utożsamianie fonemu $\mathrm{z}$ głoską, niedostrzeganie szerszej funkcji słuchu fonemicznego, pomijanie roli świadomości grafemicznej w nauce czytania.

C. K. Leong (Hong Kong), N. Nitta (Kanada) i J. Yamada (Japonia) w artykule Phonological Analysis Abilities of Chinese and Japanese Children Learning to Read relacjonują badania nad naturą fonologicznej i fonemicznej świadomości w czytaniu morfosylabicznego pisma chińskiego oraz japońskiego sylabicznego pisma kana. Rolę świadomości fonologicznej w czytaniu znaków pisma chińskiego i japońskiego (do tej pory 
uważanych za pismo odczytywane globalnie) potwierdzają gry językowe dzieci chińskich i japońskich, popełniane przez nie błędy w mowie i piśmie oraz badania prowadzone na gruncie psychologii eksperymentalnej. Autorzy stawiają hipotezę, że na percepcję segmentów fonologicznych ma wpływ specyfika pisma (script-effect hypothesis).

Ostatni artykuł pierwszej części nosi tytuł The Relationship between Phoneme Awareness and Rapid Serial Naming Skills and Literacy Acquisition: The Role of Reading Level and Ability. Autorzy, C. Cardoso-Martins (Brazylia) i B. F. Pennington (USA), relacjonują swe wieloletnie badania nad zależnościami między świadomością fonologiczną (PA - Phoneme Awareness) i umiejętnością szybkiego seryjnego nazwania (RSN - Rapid Serial Naming) a przyswajaniem umiejętności czytania i pisania (LA - Literacy Acquisition). Wyniki ich badań wskazują, że umiejętność szybkiego seryjnego nazywania (np. liter i liczb) na wczesnym etapie nauki czytania i pisania jest - wbrew dotychczasowemu powszechnemu mniemaniu bardziej powiązana z poziomem czytania niż wynik testu świadomości fonologicznej, a z kolei świadomość fonologiczna jest raczej efektem nauki czytania i pisania niż koniecznym warunkiem jej rozpoczęcia.

Część II książki zatytułowana jest Role of Orthography in Cognitive Theories of Reading (s. 67-130). Rozpoczyna ją artykuł A. Sadoskiego (USA) The Role of Orthography in a Dual Coding Theory of Reading. Autor przedstawia w nim założenia Dual Coding Theory (DCT), ogólnej teorii poznania stosowanej $w$ badaniach nad przyswajaniem nauki czytania i pisania. DCT zakłada, że poznanie opiera się na funkcjonowaniu dwóch niezależnych systemów, z których jeden specjalizuje się w językowej, a drugi w niewerbalnej wiedzy o świecie. Dowody na DCT Sadoski znajduje w licznych eksperymentach nad rolą ortografii w czytaniu.

I. Raman (Cypr) w artykule Lexicality Effects in Single-word Naming in Alphabetic Turkish Orthography opisuje badania procesów poznawczych $\mathrm{w}$ rozpoznawaniu pojedynczych słów w transparentnej, tj. opartej na przejrzystych relacjach między grafemem a fonemem, ortografii tureckiej. Wyniki eksperymentów pozwalają stwierdzić, że dorosły czytelnik języka tureckiego czyta globalnie, a w wyjątkowych wypadkach (np. rozpoznając pseudowyrazy) zmienia strategię czytania na fonetyczną. 
Kolejne dwa teksty poświęcone są transparentnej ortografii hiszpańskiej. J. S. Sainz, A. Gutierrez i C. Villalba w artykule Illusory Words: Orthographic and Lexical Constraints in Letter Migration szukają odpowiedzi na pytanie, w jaki sposób mowa jest generowana przez pismo i jaki to ma związek $z$ typem ortografii. $W$ psychologii poznawczej popularne są dwie hipotezy na temat relacji między zapisem a dźwiękiem: jedna (dual route model) zakłada, że czytelnik wykorzystuje dwie drogi: dekodowanie (przetwarzanie reguł zależności między grafemem a fonemem) oraz czytanie globalne (bezpośredni dostęp do leksykonu), a druga (single route model) twierdzi, że do odczytania większości wyrazów wystarcza pojedynczy mechanizm. Badania błędów polegających na substytucji pojedynczych liter oraz eksperymenty z pseudohomofonami, czyli wyrazami nieistniejącemi $\mathrm{w}$ danym języku, ale brzmiącymi jak prawdziwe wyrazy, skłaniają autorów do opowiedzenia się po stronie modelu drugiego.

Z kolei R. Titos (Hiszpania), S. Defior (Hiszpania), J. Alegria (Belgia) i F. Martos (Hiszpania) w artykule The Use of Morphological Resources in Spanish Orthography: The Case of the Verb szukają odpowiedzi na pytanie, $\mathrm{w}$ jakim zakresie informacja morfologiczno-syntaktyczna jest wykorzystywana w tzw. "ortografii płytkiej” (czyli takiej, w której odpowiedniości między fonemem a grafemem są bardzo regularne i w której informacja fonologiczna wystarcza do poprawnego napisania większości słów). Autorzy prowadzili badania hiszpańskich dzieci w trakcie pierwszych trzech lat ich nauki w szkole i badali, w jaki sposób dzieci zapisują "nieme” części wyrazu (pisane, ale niewymawialne). Ich eksperymenty dowodzą, że dzieci częściej zapisują "niemą" część wyrazu wtedy, gdy niesie ona informację morfologiczną (np. końcowe -s jako wykładnik 2 os. lp. czasownika) niż wtedy, gdy jest ona pozbawiona takiej informacji, tym samym autorzy obalają rozpowszechnione przekonanie, jakoby $w$ ortografii transparentnej informacja morfologiczno-syntaktyczna nie była wykorzystywana.

Część drugą zamyka artykuł M. N. Trindade (Portugalia) Portuguese Orthography: Some Notes, poświęcony systemowemu opisowi języka portugalskiego (systemu samogłoskowego i spółgłoskowego, dyftongów, struktury sylaby) i jego relacji do ortografii.

Część III Learning to Spell (s. 131-184) zawiera cztery artykuły doty- 
czące nauki pisania w różnych systemach językowych. S. Defior, F. Martos i E. Aguilar w tekście Influence of Reading Level on Word Spelling according to the Phoneme-Grapheme Relationship relacjonują badania nad przyswajaniem umiejętności pisania w języku hiszpańskim i jej związkiem z poziomem umiejętności czytania. Wyniki badań jednoznacznie dowodzą bliskich relacji między obiema umiejętnościami.

Kolejny artykuł zatytułowany Inquiry into Expert Knowledge about Effective Spelling Exercises poświęcony jest nauczaniu pisania w języku holenderskim. M. Bos i P. Reitsma relacjonują w nim badania nad efektywnością 56 typów ćwiczeń wykorzystywanych w nauczaniu holenderskiej ortografii.

R. M. Joshi (USA) i P.G. Aaron (USA) w artykule A New Way of Assessing Spelling Ability and its Classroom Implications proponują nowy w amerykańskiej szkole sposób oceniania umiejętności ortograficznych dzieci. Krytyka dotychczasowego sposobu oceniania wydaje się uzasadniona: w eksperymencie polegającym na dwukrotnym sprawdzeniu umiejętności dzieci dwoma narzędziami oceny: tradycyjnym i nowym, w drugim wypadku dzieci uzyskiwały lepsze wyniki, ponadto nowe narzędzie pozwalało nauczycielom precyzyjniej diagnozować potrzeby i braki uczących się.

Artykuł G. Th. Pavlidis (USA) i V. Giannouli (Grecja) Spelling Errors Accurately Differentiate USA-English Speakers from Greek Dyslexics: Implication for Causality and Treatment wpisuje się w szerszą dyskusję nad problematyką dysleksji w różnych językach. Autorzy stawiają sobie za cel ustalenie, czy dyslektyczne dzieci greckie i anglojęzyczne popełniają $\mathrm{w}$ piśmie te same typy błędów. Wyniki przeprowadzonych badań dowodzą, że pod względem ilościowym różnic prawie nie ma, ale istnieją istotne różnice jakościowe, wynikające ze specyfiki systemów ortograficznych obu języków. Autorzy formułują też wnioski praktyczne, dotyczące odmiennego postępowania terapeutycznego w stosunku do dyslektyków posługujących się różnymi językami.

Część IV zatytułowana Integrating Orthography and Phonology in Learning to Read (185-215) zawiera cztery artykuły, których autorzy koncentrują się na istocie procesu czytania. P. G. Patel (Kanada) w tekście Phonology in Learning to Read: Integrating Orthography into the Child's Language Processing System, przywołując badania nad różnymi językami, 
rozważa, w jaki sposób nauka czytania buduje i wzbogaca system językowego przetwarzania dziecka. Autor konkluduje, że zajmujący się problematyką przyswajania umiejętności czytania lingwiści zaczynają odchodzić od badań nad fonemem i sylabą w kierunku badań nad innymi jednostkami językowymi, mechanizmami artykulacyjnymi i procesami percepcyjnymi, a nowe obszary badawcze wymagają wypracowania nowych narzędzi badawczych.

O wykorzystaniu nowych możliwości technologicznych w nauce czytania piszą amerykańscy naukowcy M. C. McKenna, D. Reinking i B. A. Bradley. W artykule The Effects of Electronic Trade Books on the Decoding Growth of Beginning Readers opisują dwa eksperymenty, których celem było zbadanie wpływu elektronicznych książek na rozwój umiejętności czytania na wczesnym etapie edukacyjnym. Autorzy założyli, że książki elektroniczne (wyposażone m.in w różne narzędzia usprawniające dekodowanie) znacznie przyśpieszą proces nabywania umiejętności czytania. Wyniki badań potwierdziły pozytywną rolę książki elektronicznej, ale nie w takim zakresie, w jakim autorzy się spodziewali.

Artykuł K. Sochackiej i G. Krasowicz-Kupis (Polska) Reading Errors of Polish Children during their First Two Years at School zawiera opis longitudinalnych badań nad błędami w czytaniu polskich dzieci. Analiza wyników pozwoliła wyróżnić dziesięć najczęściej pojawiających się błędów, a ich nasilenie i rozłożenie w czasie umożliwiają odtworzenie przebiegu przyswajania umiejętności czytania u polskich dzieci we wczesnym okresie nauki. Polega on na przechodzeniu od prostego dekodowania do czytania dla poszukiwania znaczenia.

Ostatni artykuł To Be or Not to Be Phonologically Aware: A Reflection about Metalinguistic Skills in Teacher Trainees poświęcony jest badaniom nad świadomością językową hiszpańskich nauczycieli. Autorzy, F. Serrano, S. Defior i F. Martos, podkreślają, że w literaturze dotyczącej nauki czytania mówi się o roli świadomości językowej, szczególnie świadomości fonologicznej, natomiast niewiele prowadzono badań nad poziomem wiedzy tych, którzy mają dziecko w świat pisma wprowadzać. Przeprowadzone analizy potwierdzają, że umiejętności metajęzykowe przyszłych nauczycieli (szczególnie nauczycieli nauczania początkowego) powinny być ćwiczone, gdyż u ludzi dorosłych, którzy 
zautomatyzowali proces czytania, wiedza fonologiczna staje się wiedzą podświadomą.

Lektura prezentowanej książki nasuwa kilka refleksji natury ogólnej. Czytelnik zyskuje świadomość, iż nauka czytania i pisania jest obecnie przedmiotem intensywnych badań interdyscyplinarnych (psychologów, psycholingwistów, neuropsychologów, językoznawców i pedagogów) i międzynarodowych. Omawiana książka nie relacjonuje wielkich międzynarodowych projektów w tym zakresie, ale zawiera bogatą bibliografię, która jednoznacznie wskazuje na interdyscyplinarne orientacje badawcze, ponadto samo ukazanie się tej książki dowodzi, że wymiana dorobku naukowego jest obecnie dobrem cenionym. Szczególnie cieszy, że nie tylko Polska, ale i Białystok ma swój udział w tej wymianie $^{2}$.

Interesujące jest wyraźne zwrócenie uwagi badaczy wszystkich specjalności na rolę faktów lingwistycznych w nauczaniu czytania i pisania. Dziś nikt nie kwestionuje stwierdzenia, że różne języki wymagają różnych umiejętności w początkowej nauce czytania i pisania, bowiem to struktura języka decyduje, jaka jednostka językowa (fonem, rym, sylaba, morfem, mora ${ }^{3}$ ) jest dostępna dla uczącego się w sposób naturalny i która $z$ nich najlepiej (w sposób najbardziej regularny) jest reprezentowana $\mathrm{w}$ systemie ortograficznym, przez co wpływa na rozwój świadomości językowej.

Na zakończenie warto dodać, że Literacy Acquisition to książka interesująca w lekturze również ze względów ogólnopoznawczych. Można w niej znaleźć informacje o odmiennym od naszego sposobie percepcji dźwięków przez Japończyków (Leong i in., s. 42); dowiedzieć się, że do początku XX wieku ortografia portugalska opierała się głównie na zasadzie etymologicznej, a pismo znacznie różniło się od wymowy (Trindade); uświadomić sobie, że podstawy ortografii holenderskiej są bardzo podobne do głównych zasad ortografii polskiej (Bos, Reitsma, s. 142).

\footnotetext{
2 Krystyna Sochacka, współautorka jednego $\mathrm{z}$ artykułów, pracuje jako adiunkt w Katedrze Psychologii Wydziału Pedagogiki i Psychologii Uniwersytetu w Białymstoku.

3 Mora jest podstawową jednostka prozodyczną języka japońskiego, pośrednią między sylabą a fonemem (np. dwie mory mogą stanowić jedną sylabę).
} 
Książka Literacy Acquisition z pewnością zainteresuje badaczy procesów czytania i pisania, ale można ją również polecić wszystkim, którzy chcieliby poszerzyć swój horyzont poznawczy o wiedzę na temat różnych języków i systemów ortograficznych.

Elżbieta Awramiuk 